ZOOLOGIA 28 (5): 663-672, October, 2011

doi: $10.1590 /$ S1984-46702011000500015

\title{
Morphological diagnosis and geographic distribution of Atlantic Forest red-rumped mice of the genus Juliomys (Rodentia: Sigmodontinae)
}

\author{
Silvia E. Pavan ${ }^{1,2} \&$ Yuri L. R. Leite ${ }^{1}$ \\ ${ }^{1}$ Laboratório de Matozoologia e Biogeografia, Departamento de Ciências Biológicas, Universidade Federal do Espírito Santo. \\ Avenida Marechal Campos 1468, Maruípe, 29043-900 Vitória, ES, Brazil. \\ ${ }^{2}$ Corresponding author. Current address: American Museum of Natural History, Division of Vertebrate Zoology. Central Park \\ West at 79th Street, 10024 New York, NY, USA. E-mail: sepavan@yahoo.com
}

\begin{abstract}
Recognition and identification of red-rumped mice of the genus Juliomys González, 2000 has been a problem among many mammalogists, and specimens of this genus are commonly confused with other Atlantic Forest sigmodontine rodents. Herein we provide an expanded diagnosis for the genus based on the analyses of the three living species of Juliomys, and provide morphological comparisons to the small bodied and bright colored rodents Rhagomys rufescens (Thomas, 1886) and Oligoryzomys flavescens (Waterhouse, 1837), which occur in sympatry with Juliomys spp. in forested areas of southeastern Brazil. These taxa are superficially similar, and are therefore commonly misidentified in the field and museum collections. We also provide morphometric data and a key to the living species of Juliomys, and an updated distribution map of the genus and its species.
\end{abstract}

KEY WORDS. Emended diagnosis; Juliomys pictipes; Juliomys rimofrons; Juliomys ossitenuis; identification key; taxonomy.

Juliomys González, 2000 is currently composed of three living species and is endemic to the Atlantic Forest of southeastern Brazil, northeastern Argentina and eastern Paraguay (De La Sancha et al. 2009). Despite recent contributions on the taxonomy and morphology for this genus (e.g., Oliveira \& Bonvicino 2002, Costa et al. 2007, Pardiñas et al. 2008, De La SANCHa et al. 2009, Pardiñas \& TeTA 2011), the recognition and identification of this recently described Sigmodontinae genus remains problematic. This is partially due to the relative low number of specimens available for comparisons in scientific collections. There are fewer than 80 museum specimens of Juliomys pictipes Osgood, 1933 - the type species of the genus and the most common species. Juliomys rimofrons Oliveira \& Bonvicino, 2002 is known only from the three type specimens, and there are fewer than 30 museum specimens of $J$. ossitenuis Costa, Pavan, Leite \& Fagundes, 2007.

Another reason for the difficulty in diagnosing this genus is historical. GonZález's (2000) description was done before the discovery of two additional species of Juliomys and the generic diagnosis was based on a single specimen (FMNH 26814, the holotype). GonzÁLEz (2000) considered OsGOoD's (1933) diagnosis of the species Thomasomys pictipes as the diagnosis for the genus, which does not reflect the present diversity in Juliomys. PARDiÑas et al. (2008) provided an emended diagnosis of the genus based mainly on three specimens of $J$. pictipes recently collected in Argentina. However, the recognition of this genus remains a problem among mammalogists, even after PARDIÑAS et al. (2008) contribution, and especially with the relative increase in captures of Juliomys specimens in the last decade (e.g., VIEIRA
\& Monteiro-Filho 2003, Neri-Bastos et al. 2004, Cherem et al. 2004, Oliveira et al. 2005, Pardini \& Umetsu 2006, Umetsu et al. 2006, Lima et al. 2010, Melo et al. 2011). Specimens of Juliomys are commonly confused with other small bodied and bright colored mice, particularly Rhagomys rufescens (Thomas, 1886) and Oligoryzomys flavescens (Waterhouse, 1837), which are often sympatric with Juliomys spp. in forested areas throughout southeastern Brazil (e.g., PARdini \& UMetsu 2006), commonly causing misidentifications in the field and museum collections.

Herein we provide an emended diagnosis for Juliomys based on analyses of all three living species, and compare it to $R$. rufescens and $O$. flavescens. We also provide morphometric data and a key to the species of Juliomys, and an updated distribution map of the genus and its species.

\section{MATERIAL AND METHODS}

We performed morphological analyses on external, cranial, and dental characters of 91 specimens of Juliomys: J. pictipes $(\mathrm{n}=59)$; J. ossitenuis $(\mathrm{n}=29)$; and J. rimofrons $(\mathrm{n}=3)$. In addition, we examined seven specimens of $O$. flavescens and three specimens of $R$. rufescens. Specimens examined are listed in Appendix I, and are deposited in the following collections: (FMNH) Field Museum, Chicago, USA; (MBML) Museu de Biologia Prof. Mello Leitão, Santa Teresa, Brazil; (MN) Museu Nacional, Universidade Federal do Rio de Janeiro, Rio de Janeiro, Brazil; (MVZ) Museum of Vertebrate Zoology, University of California, Berkeley, USA; (MZUFV) Museu de Zoologia João Moojen de Oliveira, Universidade Federal de Viçosa, Viçosa, 
Brazil; (MZUSP) Museu de Zoologia, Universidade de São Paulo, São Paulo, Brazil; (UFES) Universidade Federal do Espírito Santo, Vitória, Brazil; (UFMG) Universidade Federal de Minas Gerais, Belo Horizonte, Brazil; (ZUEC-MAM) Museu de Zoologia da Universidade Estadual de Campinas, Campinas, Brazil.

Other acronyms for institutions and collections mentioned in the text are: (CIES) Centro de Investigaciones Ecológicas Subtropicales, Puerto Iguazú, Argentina; (CNP) Colección de Mamíferos del Centro Nacional Patagónico, Puerto Madryn, Argentina; (MLP) Museo de La Plata, Buenos Aires, Argentina; (UFSC) Universidade Federal de Santa Catarina, Florianópolis, Brazil; (CZ) Colección de Zoología, Universidad Nacional de Asunción, San Lorenzo, Paraguay; (MCNU) Museu de Ciências Naturais da Universidade Luterana do Brasil, Canoas, Brazil; (UFSM) Universidade Federal de Santa Maria, Santa Maria, Brazil.

Morphological nomenclature follows definitions illustrated in Carleton (1980), Carleton \& Musser (1989), and Voss (1993). External body measurements - total length (TotL), length of tail (Tail), length of hind foot (HF), length of ear (Ear) - and body weight were taken from museum tags or field notes. We took 28 cranial measurements following CosTA et al. (2007), using a digital caliper to the nearest $0.01 \mathrm{~mm}$ : occipto-nasal length (ONL), palatal length (PL), postpalatal length (PPL), molar row-crown length (MRC), first molar breadth (M1B), palatal bridge length (PBL), temporal fossa length (TFL), diastema length (DL), incisive foramen length (IFL), incisive foramen breadth (IFB), palatal breadth at first molar (PB1), palatal breadth at third molar (PB3), mesopterygoid fossa breadth (MFB), breadth across incisor tips (BIT), bullar width (BW), bullar length (BL), braincase breadth (BCB), skull height (SH), rostral height $(\mathrm{RH})$, rostral breadth $(\mathrm{RB})$, rostral length $(\mathrm{RL})$, nasal length (NL), zygomatic plate length (ZPL), interorbital breadth (IOB), zygomatic breadth (ZB), greatest length of mandible (GLM), mandibular molar row-alveolar length (MMR), depth of ramus (DR). We classified specimens in four dental age classes according to tooth-wear and dental-eruption following Costa et al. (2007). The specimens placed in age class 1 are juveniles (third molar unerupted and/or unworn), and those in age classes 2-4 are adults (all the three molars erupted, enamel surfaces of at least one molar worn).

\section{TAXONOMY}

\section{Juliomys González, 2000}

Included species. J. pictipes (Osgood, 1933); J. rimofrons Oliveira \& Bonvicino, 2002; J. ossitenuis Costa, Pavan, Leite \& Fagundes, 2007. Pardiñas \& Teta (2011) recently suggested the reallocation of Calomys anoblepas Winge, 1887 to Juliomys. This fossil is known only from a fragmentary skull and probably represents an extinct form (PARDIÑAS \& TeTA 2011).

Type species. J. pictipes (Osgood, 1933).

Type Locality. The original type locality "Caraguatay, Rio Parana, 100 miles south of Rio Iguassu, Misiones, Argentina"
(Osgood 1933) was restricted to Puerto Caraguatay (26 37's, $\left.54^{\circ} 46^{\prime} \mathrm{W}, 192 \mathrm{~m}\right)$, Montecarlo, Misiones, Argentina, by PARDIÑAS et al. (2007).

Emended diagnosis. Small-bodied sigmodontine genus (TotL: 165-238 mm in adults); dorsal pelage soft, brownish ochraceous to orange-brown, with shades of orange especially on the rump (Fig. 1); ventral fur grayish basally and white to whitish-brown distally (Fig. 1); four pairs of mammae: two inguinal, one post-axial, and one pectoral; tail equal to or slightly longer than head and body, commonly bicolored, with small scales, and a small tuft at the tip; fore and hindfeet short and broad, dorsally covered with orange to brownish hair; claws dorsally covered by silvery white hairs reaching or extending slightly beyond the claw tips; fore and hindfeet show large, bulbous plantar pads: two carpal and three interdigital on the former and two tarsal and four interdigital on the latter (Fig. 4); Skull small and delicate (ONL: 21.95-27.56 in adults), with short rostrum (Fig. 7); interorbital region hour-glass shaped with rounded or gently angled edges; zygomatic arches slightly compressed anteriorly; zygomatic plates nearly vertical, slightly inclined forward; zygomatic notch shallow and rounded; mandible small and delicate; upper incisors opisthodont; molars large (MRC: 3.33-4.24 mm in adults), pentalophodont; well developed and separated procingulum cusps on $\mathrm{M}^{1}$; paracone and posterior cusps of $\mathrm{M}^{3}$ reduced.

Comparisons. Juliomys spp. specimens are superficially similar to $R$. rufescens and O. flavescens in size and fur color. However, differences among them are evident in both external and skull characters (Tab. I). Members of Juliomys can be distinguished from $R$. rufescens mainly by: a darker fur, with rump and hind legs distinctly orange, contrasting with the rest of the body; this contrast is not observed in Rhagomys Thomas, 1917, which shows a more homogeneous bright orange fur (Figs 1-3); tips of ventral hairs whitish to light-brown instead of orange; four pairs of mammae instead of three; slightly longer hindfeet, with smaller and narrower interdigital pads (Figs 46); hindfeet bearing a projecting claw on the first digit, instead of a round claw, resembling a nail; skull smaller, slender and more delicate (Figs 7-9); rostrum, interorbital region and zygomatic plate narrower; parapterygoid plate wider; anterior margin of mesopterygoid fossa reaching $\mathrm{M}^{3}$, while in Rhagomys, this structure does not reach $\mathrm{M}^{3}$; dentary smaller (Figs 10-12), and molar cusps less conspicuous.

Juliomys species differ from $O$. flavescens mainly by: a brighter orange fur, with rump and hind legs distinctly orange, contrasting with the rest of the body, but this contrast is not observed in Oligoryzomys Bangs, 1900, which shows a more homogeneous grayish/brownish fur (Figs 1-3); shorter tail, with smaller scales; mammae pairs in different positions: two inguinal, one post-axial, and one pectoral in Juliomys, instead of one inguinal, one abdominal, one post-axial, and one pectoral in $O$. flavescens; hindfeet shorter and wider, with interdigital pad larger and pads typically round (Figs 4-6); skull wider (Figs 


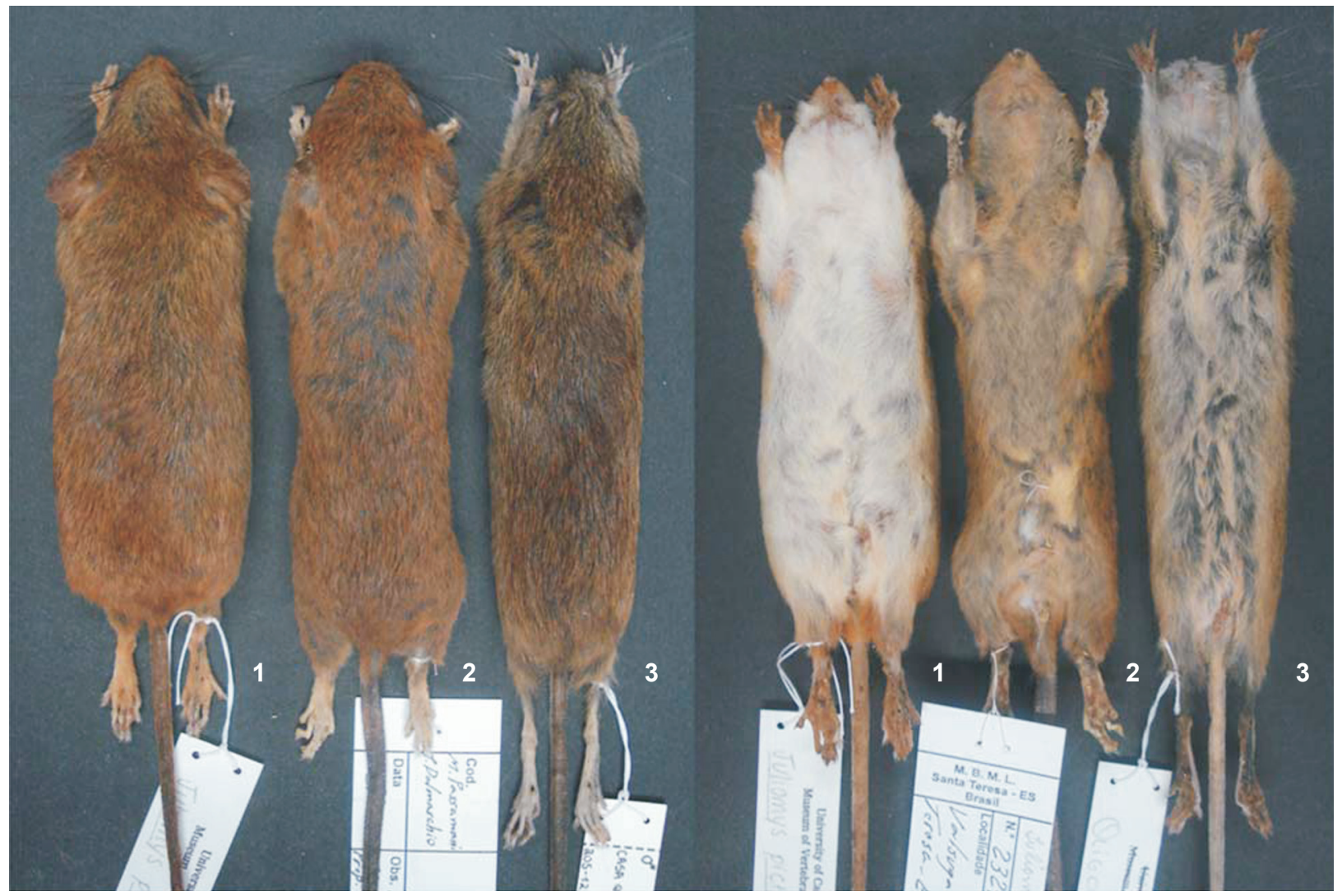

Figures 1-3. Dorsal and ventral views of the skins of: (1) J. pictipes (UFMG 3168); (2) Rhagomys rufescens (AB 401); (3) Oligoryzomys flavescens (UFES 1176).

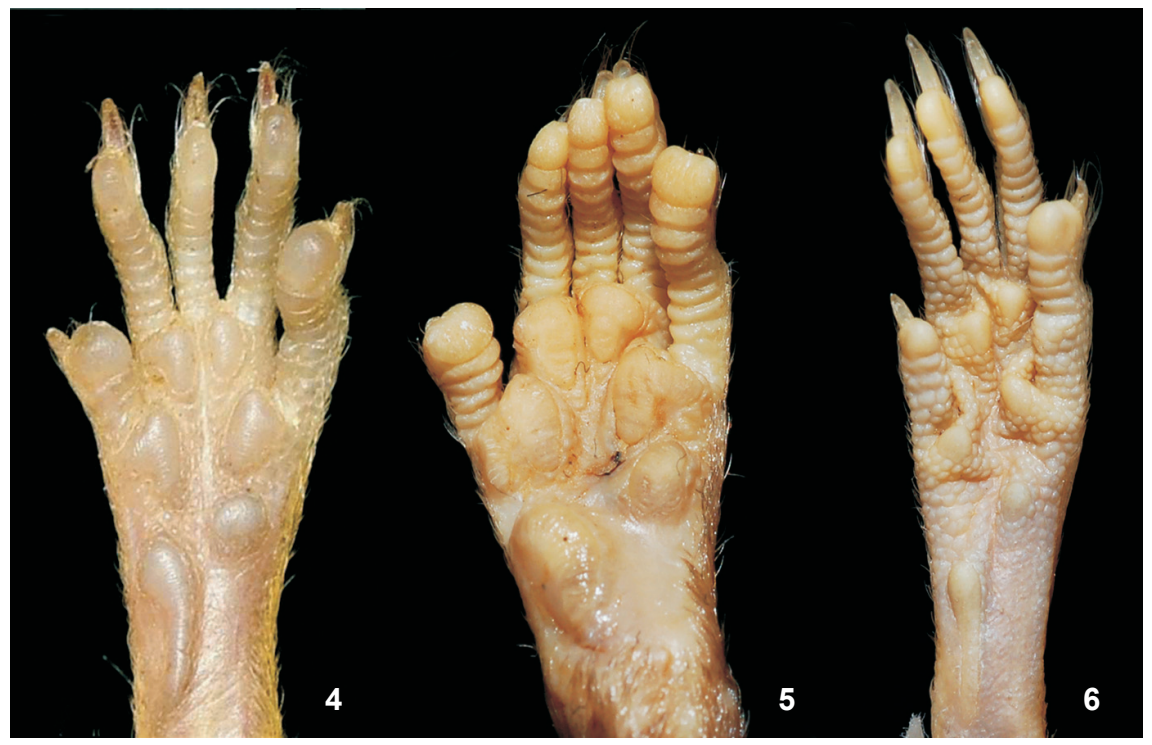

Figures 4-6. Ventral view of the left hindfoot of: (4) Juliomys ossitenuis (MBML 27833 - length of hind foot [HF] = $20 \mathrm{~mm}$ ); (5) Rhagomys rufescens ( $\mathrm{AB} 401-\mathrm{HF}=19 \mathrm{~mm}$ ); (6) Oligoryzomys flavescens (UFES $1255-\mathrm{HF}=24 \mathrm{~mm}$ ). 


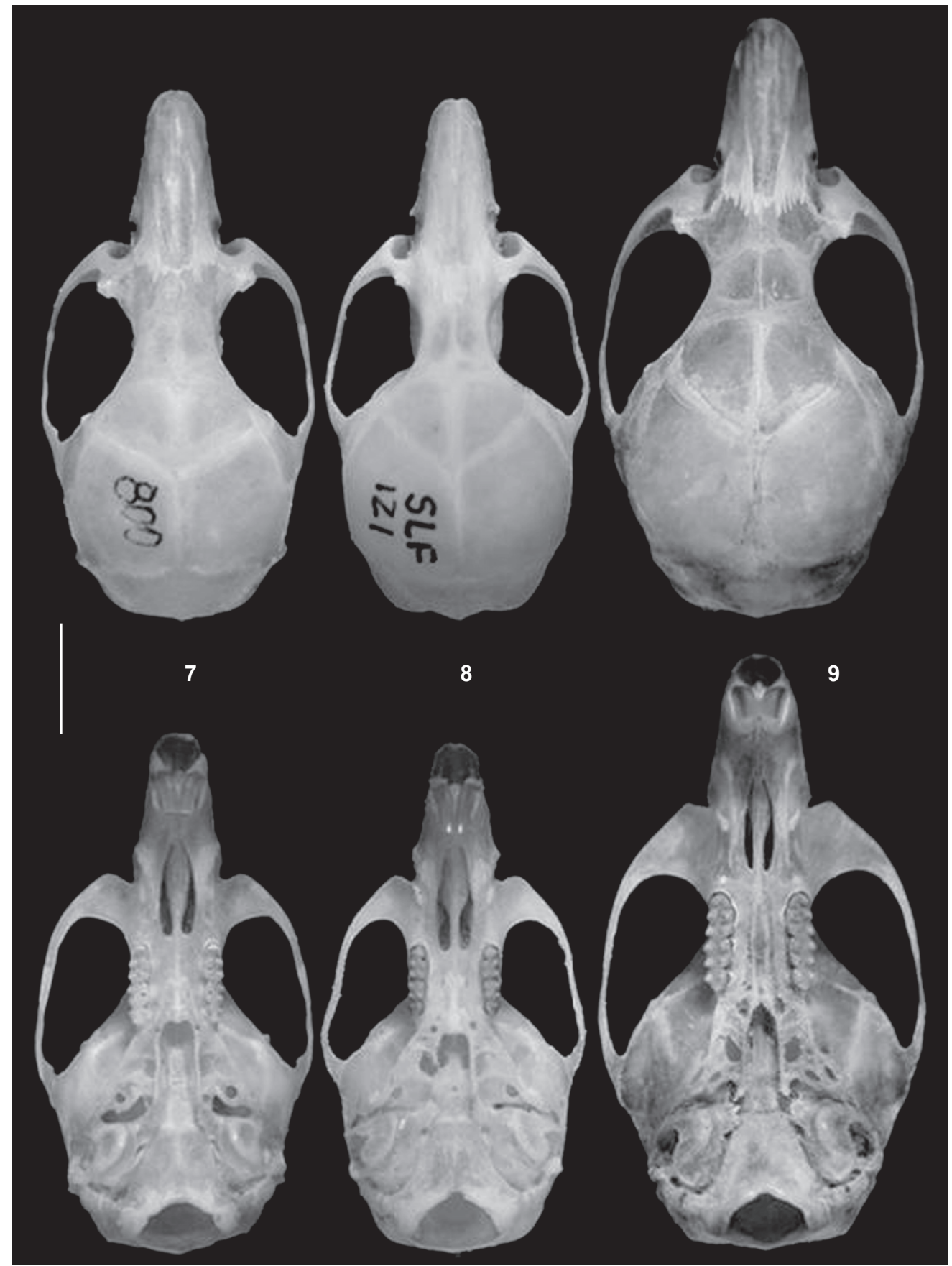

Figures 7-9. Dorsal (above) and ventral (below) views of the skulls of: (7) Juliomys pictipes (UFMG 3165); (8) Oligoryzomys flavescens (UFES 1177); (9) Rhagomys rufescens (AB 401). Scale bar $=5 \mathrm{~mm}$.

7-9); zygomatic notch shallower; interorbital region wider; anterior margin of mesopterygoid fossa reaching $\mathrm{M}^{3}$, while in O. flavescens this structure does not reach $\mathrm{M}^{3}$; condyloid process of the dentary well developed in Juliomys spp. (Figs 10-12); molar series larger, with developed anteromedian and anterior flexi on $\mathrm{M}^{1}$. The basic descriptive statistics of external and cranial measurements of species of Juliomys is given in Table II, and a summary of diagnostic characters of species of Juliomys 
Table I. Selected comparative diagnostic characters of Juliomys spp., Oligoryzomys flavescens, and Rhagomys rufescens.

\begin{tabular}{|c|c|c|c|}
\hline \multirow{2}{*}{ Character } & \multicolumn{3}{|c|}{ Taxon } \\
\hline & Juliomys spp. & Oligoryzomys flavescens & Rhagomys rufescens \\
\hline Relative body size & Small & Small & Medium \\
\hline Dorsal pelage (Figs 1-3) & $\begin{array}{l}\text { Brownish ochraceous to orange- } \\
\text { brown }\end{array}$ & Grayish/brownish & Orange-brown \\
\hline Rump and hind legs (Figs 1-3) & $\begin{array}{l}\text { Distinctly more orange than the rest } \\
\text { of the dorsum }\end{array}$ & $\begin{array}{l}\text { Same color than the rest of the } \\
\text { dorsum }\end{array}$ & Same color than the rest of the dorsum \\
\hline Tail & Nearly equal to head and body & Longer than head and body & Nearly equal to head and body \\
\hline Ventral pelage (Figs 1-3) & Hair tips whitish to light-brown & Hair tips cream to light-brown & Hair tips orange \\
\hline Mammae & $\begin{array}{l}\text { Four pairs: } 2 \text { inguinal, } 1 \text { post-axial, } 1 \\
\text { pectoral }\end{array}$ & $\begin{array}{l}\text { Four pairs: } 1 \text { inguinal, } 1 \text { abdominal, } 1 \\
\text { post-axial, } 1 \text { pectoral }\end{array}$ & $\begin{array}{l}\text { Three pairs: } 1 \text { inguinal, } 1 \text { abdominal, } 1 \\
\text { pectoral }\end{array}$ \\
\hline Hind feet (Figs 4-6) & Short, wide & Long, narrow & Shortest, widest \\
\hline Interdigital pads (Figs 4-6) & Large, bulbous & Small, narrow & Much larger, very bulbous \\
\hline Hind feet first digit claw (Figs 4-6) & Projected & Projected & Round \\
\hline Braincase (Figs 7-9) & Small and elongated & Small and elongated & Robust and inflated \\
\hline Zigomatic plate (Figs 7-9) & Narrow & Narrow & Broad \\
\hline Zigomatic notch (Figs 7-9) & Shallow & Deep & Deep \\
\hline Rostrum (Figs 7-9) & Narrow and long & Narrow and long & Wide and short \\
\hline Interorbital region (Figs 7-9) & Narrow & Much narrower & Wide \\
\hline Incisive foramen (Figs 7-9) & Large & Large & Small \\
\hline Palate (Figs 7-9) & Short & Short & Long \\
\hline $\begin{array}{l}\text { Anterior margin of mesopterygoid } \\
\text { fossae (Figs 7-9) }\end{array}$ & Reaches or goes beyond $\mathrm{M}^{3}$ & Does not reach $\mathrm{M}^{3}$ & Does not reach $\mathrm{M}^{3}$ \\
\hline Parapterygoid plate (Figs 7-9) & Wide and triangle-shaped & Wide and triangle-shaped & $\begin{array}{l}\text { Narrow, with the external margin } \\
\text { nearly parallel to mesopterygoid fossae }\end{array}$ \\
\hline Dentary (Figs 10-12) & $\begin{array}{l}\text { Small, delicate, with a sinuous } \\
\text { inferior margin }\end{array}$ & $\begin{array}{l}\text { Quite small, delicate, with a sinuous } \\
\text { inferior margin }\end{array}$ & $\begin{array}{l}\text { Broad, robust, with straight inferior } \\
\text { margin }\end{array}$ \\
\hline Condyloid process (Figs 10-12) & Developed & Underdeveloped & Developed \\
\hline Molar series & Large & Small & Large \\
\hline Molar cusps & $\begin{array}{l}\text { Inconspicuous, nearly triangle } \\
\text { shaped }\end{array}$ & Inconspicuous, nearly triangle shaped & $\begin{array}{l}\text { Conspicuous, isolated and conical, } \\
\text { diagonally projected }\end{array}$ \\
\hline $\begin{array}{l}\text { Anteromedian and anterior flexis } \\
\text { on } \mathrm{M}^{1}\end{array}$ & Developed & Underdeveloped & Developed \\
\hline $\begin{array}{l}\text { Anterolabial and anterolingual } \\
\text { cusps of procingulum }\end{array}$ & Clearly divided & Faintly divided & Clearly divided \\
\hline
\end{tabular}

is given in Costa et al. (2007: 29, Tab. II).

Geographic distribution. Juliomys spp. occur in the Atlantic Forest from southeastern Brazil to northeastern Argentina and eastern Paraguay (Fig. 13). Brazilian localities of the three living species were provided in Costa et al. (2007). Subsequently, new records of $J$. pictipes were reported from Argentina (PARDIÑAS et al. 2008, Fig. 13, localities 40, 43, 45), Paraguay (De La SANCHA et al. 2009, Fig. 13, locality 39), and the states of Espírito Santo (Tonini et al. 2010, Fig. 13, locality 3) and Rio Grande do Sul (Melo et al. 2011, Fig. 13, locality 47), in Brazil. Cherem et al. (2004) identified some specimens from the state of Santa Catarina, southern Brazil as J. pictipes (Fig. 13, locality 46) and others as Juliomys sp. (Fig. 13, localities 47, 42, 41). They stated that the latter probably does not belong to J. pictipes, but did not provide any further explanations about their taxonomic assessment. Cherem (2005) also reported Juliomys sp. from Siderópolis, Santa Catarina, southern Brazil (Fig. 13, locality 48). De LA SANCHA et al. (2009) included Cherem's (2005) record as J. pictipes, but since apparently they have not examined any specimen, we kept this record under Juliomys sp. PARESQUe et al. (2009) described a new karyotype from Juliomys specimens collected at Aparados da Serra National Park, state of Rio Grande do Sul, southern Brazil (Fig. 13, locality 49). Since the karyotype represents a powerful tool to diagnose Juliomys species, these authors suggested that this new karyomorph represents an undescribed species of the genus (PAREsQue et al. 2009). Lima et al. (2010) reported the 
Table II. Descriptive statistics for measurements $(\mathrm{mm})$ and weight $(\mathrm{g})$ of adult (dental age classes 2-4) specimens of Juliomys, grouped by species. (N) Sample size, (S.D.) Standard Deviation, (Min) minimum, (Max) maximum. For other abbreviations see material and methods.

\begin{tabular}{|c|c|c|c|c|c|c|c|c|c|c|c|c|c|c|c|}
\hline \multirow[b]{2}{*}{ Character } & \multicolumn{5}{|c|}{ Juliomys ossiteuis } & \multicolumn{5}{|c|}{ Juliomys rimofrons } & \multicolumn{5}{|c|}{ Juliomys pictipes } \\
\hline & Mean & $\mathrm{N}$ & S.D. & Min. & Max. & Mean & $\mathrm{N}$ & S.D. & Min. & Max. & Mean & $\mathrm{N}$ & S.D. & Min. & Max. \\
\hline TotL & 182.00 & 17 & 14.04 & 165.00 & 213.00 & 194.67 & 3 & 17.47 & 180.00 & 214.00 & 195.45 & 38 & 13.82 & 170.00 & 238.00 \\
\hline Tail & 104.53 & 17 & 7.29 & 89.00 & 116.00 & 108.33 & 3 & 11.37 & 99.00 & 121.00 & 106.03 & 38 & 8.25 & 92.00 & 138.00 \\
\hline $\mathrm{HF}$ & 19.68 & 17 & 2.52 & 14.00 & 23.00 & 21.33 & 3 & 1.15 & 20.00 & 22.00 & 20.99 & 38 & 1.92 & 16.00 & 27.00 \\
\hline Ear & 14.23 & 15 & 1.82 & 10.00 & 17.00 & 16.00 & 3 & 1.73 & 15.00 & 18.00 & 15.08 & 36 & 1.75 & 10.00 & 19.00 \\
\hline Weight & 18.05 & 11 & 4.85 & 11.00 & 28.00 & 19.83 & 3 & 4.65 & 14.50 & 23.00 & 22.90 & 31 & 5.51 & 11.50 & 33.00 \\
\hline ONL & 24.20 & 21 & 1.24 & 21.95 & 26.83 & 24.96 & 3 & 1.29 & 23.49 & 25.92 & 25.66 & 38 & 1.17 & 23.04 & 27.56 \\
\hline PL & 10.87 & 22 & 0.63 & 9.80 & 12.08 & 11.33 & 3 & 0.62 & 10.61 & 11.73 & 11.56 & 38 & 0.64 & 10.37 & 12.68 \\
\hline PPL & 8.49 & 22 & 0.57 & 7.47 & 9.78 & 8.47 & 3 & 0.55 & 7.88 & 8.96 & 9.05 & 39 & 0.63 & 7.69 & 10.28 \\
\hline MRC & 3.71 & 22 & 0.15 & 3.33 & 3.99 & 3.81 & 3 & 0.06 & 3.75 & 3.86 & 3.91 & 39 & 0.15 & 3.63 & 4.24 \\
\hline M1B & 1.03 & 22 & 0.05 & 0.94 & 1.14 & 1.08 & 3 & 0.03 & 1.05 & 1.11 & 1.11 & 39 & 0.07 & 0.98 & 1.44 \\
\hline PBL & 3.57 & 22 & 0.21 & 3.25 & 4.03 & 3.67 & 3 & 0.14 & 3.53 & 3.81 & 3.98 & 39 & 0.24 & 3.47 & 4.57 \\
\hline TFL & 7.38 & 21 & 0.48 & 6.56 & 8.38 & 7.67 & 3 & 0.43 & 7.18 & 7.96 & 7.97 & 39 & 0.36 & 7.18 & 8.71 \\
\hline $\mathrm{DL}$ & 6.16 & 22 & 0.52 & 5.47 & 7.44 & 6.18 & 3 & 0.38 & 5.74 & 6.41 & 6.25 & 38 & 0.42 & 5.27 & 7.02 \\
\hline IFL & 4.58 & 22 & 0.30 & 3.83 & 5.36 & 4.84 & 3 & 0.37 & 4.46 & 5.19 & 4.57 & 39 & 0.27 & 4.05 & 5.26 \\
\hline IFB & 1.74 & 22 & 0.16 & 1.34 & 2.13 & 1.65 & 3 & 0.03 & 1.62 & 1.67 & 1.68 & 39 & 0.11 & 1.44 & 2.11 \\
\hline PB1 & 2.43 & 22 & 0.13 & 2.21 & 2.65 & 2.69 & 3 & 0.24 & 2.43 & 2.91 & 2.33 & 39 & 0.15 & 2.09 & 2.71 \\
\hline PB3 & 2.78 & 22 & 0.19 & 2.34 & 3.12 & 3.06 & 3 & 0.36 & 2.65 & 3.35 & 2.69 & 39 & 0.17 & 2.37 & 3.07 \\
\hline MFB & 1.71 & 22 & 0.15 & 1.41 & 1.97 & 1.64 & 3 & 0.17 & 1.44 & 1.76 & 1.75 & 38 & 0.13 & 1.49 & 2.04 \\
\hline BIT & 1.48 & 22 & 0.15 & 1.24 & 1.76 & 1.55 & 3 & 0.14 & 1.38 & 1.64 & 1.66 & 39 & 0.13 & 1.42 & 1.89 \\
\hline BW & 3.71 & 22 & 0.18 & 3.30 & 3.98 & 4.09 & 3 & 0.13 & 3.94 & 4.18 & 3.65 & 39 & 0.16 & 3.33 & 3.94 \\
\hline$B L$ & 4.65 & 22 & 0.16 & 4.36 & 5.03 & 4.80 & 3 & 0.19 & 4.64 & 5.01 & 4.37 & 39 & 0.16 & 4.08 & 4.79 \\
\hline $\mathrm{BCB}$ & 10.25 & 22 & 0.39 & 9.50 & 10.88 & 10.84 & 3 & 0.24 & 10.57 & 10.99 & 10.31 & 39 & 0.43 & 9.31 & 10.98 \\
\hline $\mathrm{SH}$ & 7.52 & 22 & 0.26 & 6.95 & 8.06 & 7.65 & 3 & 0.14 & 7.54 & 7.81 & 7.78 & 39 & 0.30 & 7.27 & 8.64 \\
\hline $\mathrm{RH}$ & 4.43 & 22 & 0.31 & 3.99 & 5.16 & 4.37 & 3 & 0.27 & 4.06 & 4.53 & 4.90 & 39 & 0.31 & 4.30 & 5.49 \\
\hline $\mathrm{RB}$ & 4.31 & 20 & 0.29 & 3.74 & 4.91 & 4.38 & 3 & 0.16 & 4.26 & 4.49 & 4.54 & 39 & 0.26 & 4.13 & 5.08 \\
\hline $\mathrm{RL}$ & 7.36 & 21 & 0.55 & 6.35 & 8.34 & 7.65 & 3 & 0.45 & 7.14 & 7.99 & 7.85 & 35 & 0.52 & 6.86 & 8.86 \\
\hline $\mathrm{NL}$ & 8.43 & 21 & 0.65 & 7.23 & 9.80 & 8.66 & 3 & 0.69 & 7.87 & 9.11 & 8.93 & 35 & 0.64 & 7.49 & 9.90 \\
\hline ZPL & 1.83 & 22 & 0.36 & 1.34 & 3.03 & 1.70 & 3 & 0.16 & 1.58 & 1.88 & 2.24 & 39 & 0.44 & 1.48 & 3.39 \\
\hline IOB & 3.76 & 22 & 0.11 & 3.57 & 3.96 & 3.72 & 3 & 0.14 & 3.58 & 3.86 & 4.00 & 39 & 0.18 & 3.60 & 4.42 \\
\hline ZB & 12.82 & 21 & 0.72 & 11.66 & 13.98 & 13.81 & 3 & 0.74 & 12.98 & 14.41 & 13.55 & 39 & 0.78 & 12.06 & 14.87 \\
\hline GLM & 12.73 & 22 & 0.61 & 11.61 & 14.01 & 12.99 & 3 & 0.68 & 12.23 & 13.53 & 13.41 & 39 & 0.66 & 12.11 & 14.71 \\
\hline MMR & 3.83 & 22 & 0.15 & 3.57 & 4.11 & 4.01 & 3 & 0.07 & 3.94 & 4.08 & 3.99 & 39 & 0.13 & 3.65 & 4.25 \\
\hline DR & 2.72 & 22 & 0.16 & 2.56 & 3.15 & 2.87 & 3 & 0.02 & 2.86 & 2.89 & 2.99 & 39 & 0.18 & 2.55 & 3.38 \\
\hline
\end{tabular}

southernmost record of Juliomys, found in a semi-deciduous forest at the austral boundary of the Atlantic Forest in the state of Rio Grande do Sul, southern Brazil. They were unable to identify it beyond genus, but suggested that it may belong to the same undescribed species reported by PAResQue et al. (2009).

Remarks. There is an apparent distribution gap in the south between most samples from southern Brazil and northeastern Argentina/eastern Paraguay, including one from northeastern Rio Grande do Sul, Brazil (Fig. 13). This is either due to a true historical biogeographic gap or a collecting artifact (scarcity of adequate inventories, combined with low abundance of Juliomys). The habitat in this region is dominated by Araucaria angustifolia (Bertol.) Kuntze pines (Araucariaceae), forming the Araucaria forest, and some small mammal studies failed to detect Juliomys spp. in this habitat (e.g. WALLAUER et al. 2000, Cademartori et al. 2004, Dalmagro \& Vieira 2005). On the other hand, J. rimoforns was collected along a trapline set on vegetation varying from a forested patch with $A$. angustifolia to 


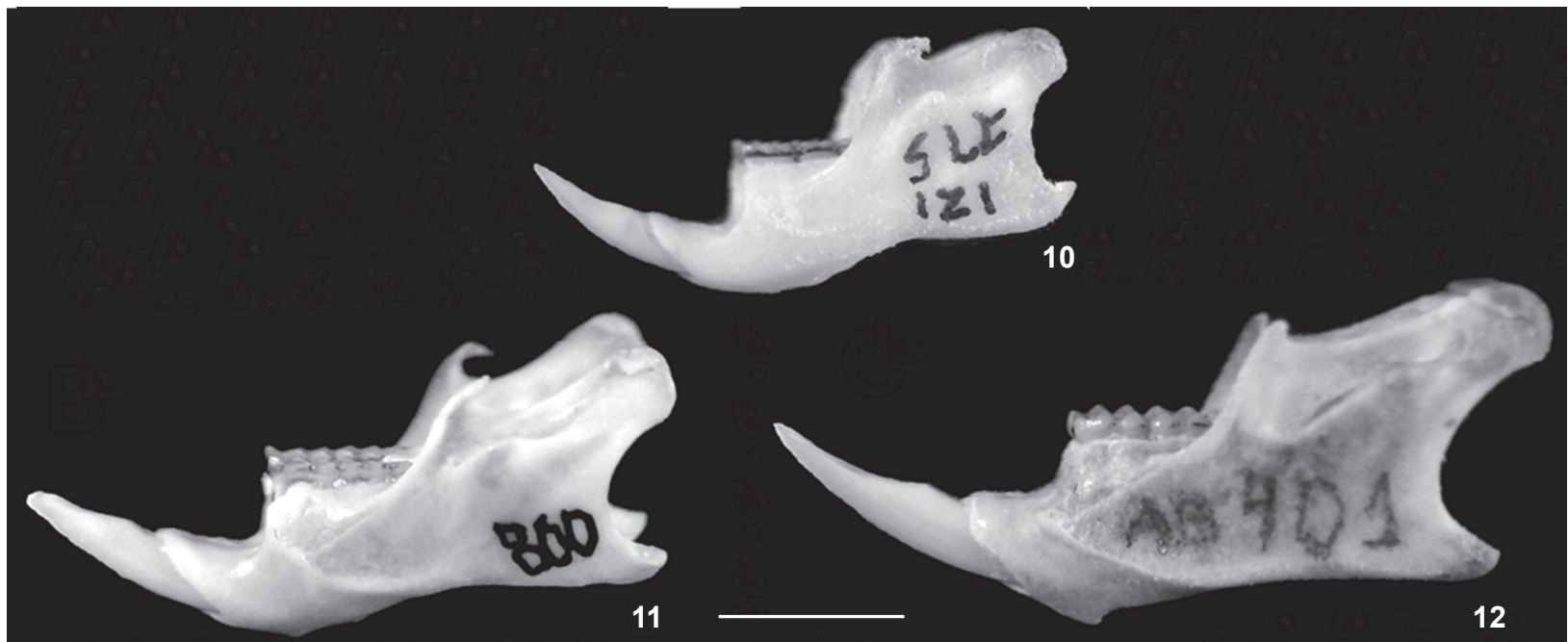

Figures 10-12. Lateral view of the mandibles of: (10) Oligoryzomys flavescens (UFES 1177); (11) Juliomys pictipes (UFMG 3165); (12) Rhagomys rufescens (AB 401). Scale bar $=5 \mathrm{~mm}$.

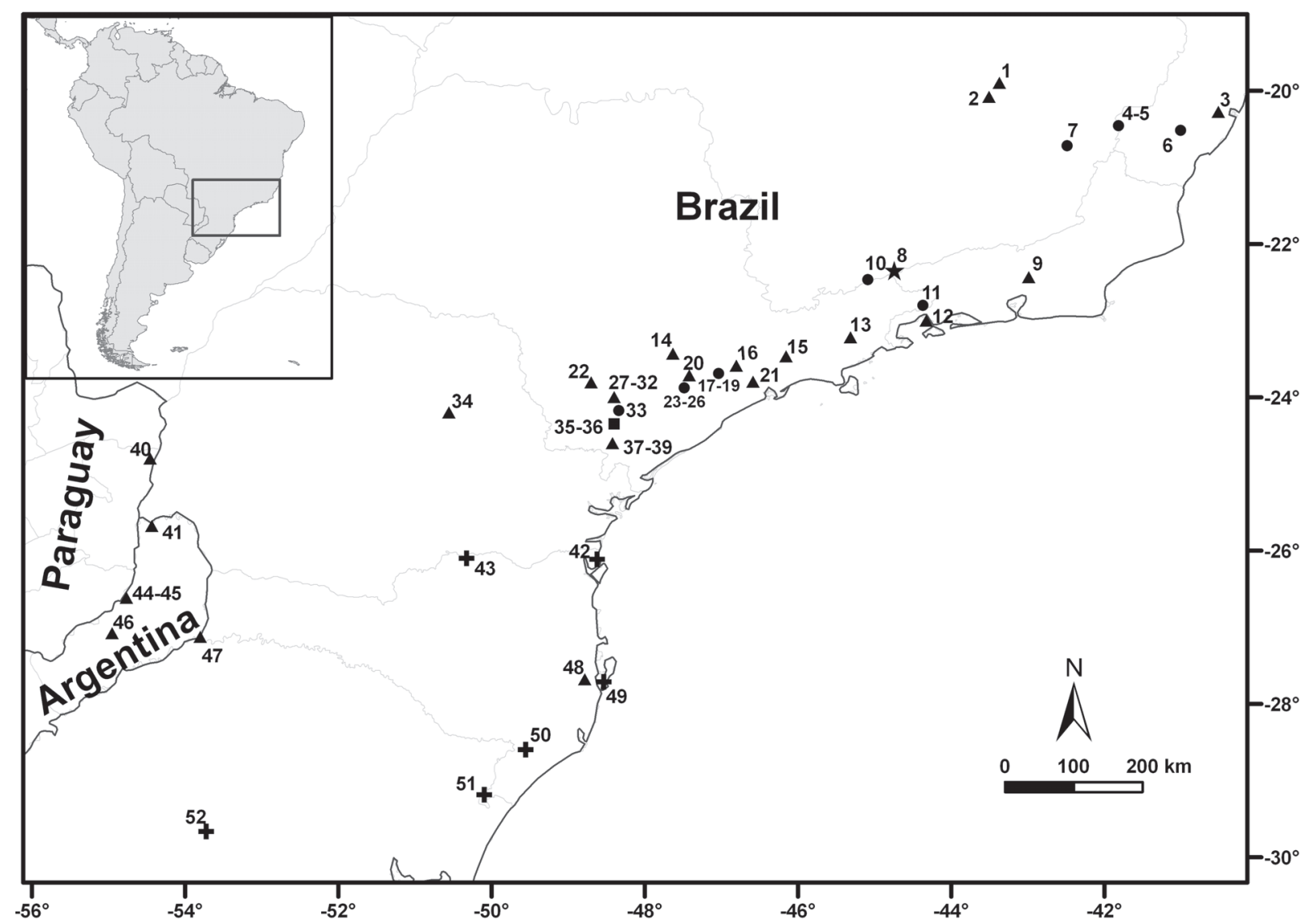

Figure 13. Collecting localities of J. ossitenuis (circles), J. pictipes (triangles) and J. rimofrons (star). Syntopy of J. ossitenuis and J. pictipes is represented by a square. Localities of specimens originally identified as Juliomys sp. (Cherem et al. 2004, Cherem 2005, PAResque et al. 2009, LIMA et al. 2010) are represented by a cross. Numbers correspond to the localities listed in Appendix I. 
patches of grasses and bromeliads (Oliveira \& Bonvicino 2002). Field inventories in this gap, combined with ecological studies on habitat preferences of Juliomys spp., will provide adequate data to answer this biogeographic question. These recent records of Juliomys, associated to the difficulties in identifying them and the existence of a potentially undescribed species call attention to our ignorance concerning the distribution and diversity of Atlantic Forest mammals in general, and small rodents in particular. Only long-term, intensive field, museum, and lab work will provide us with adequate knowledge regarding this important biodiversity hotspot.

\section{Key to the three living species of Juliomys}

1. Nose orange; dorsal pelage short, brownish ochraceous to orange-brown; ventral pelage whitish 2

$1^{\prime}$. Nose brown; dorsal pelage long, dark-brown, with shades of orange only on the rump; ventral pelage light-brown; braincase robust and inflated; squamosal-alisphenoid groove present..... Juliomys rimofrons

2. Dorsal pelage dark orange-brown; ventral pelage cream-white; tail slightly bicolored; braincase small and delicate; squamosal-alisphenoid groove present ..... Juliomys ossitenuis

2 '. Dorsal pelage brownish ochraceous to light orange-brown, with nose and rump intensely orange colored; ventral pelage white; tail markedly bicolored; braincase robust; squamosalalisphenoid groove absent ...... Juliomys pictipes

\section{ACKNOWLEDGEMENTS}

We thank the following curators and collection support staffs for making specimens available: J.A. de Oliveira, S. Franco (MN); M. de Vivo, J.G. de Barros (MZUSP); G.A.B. da Fonseca, R.T. Moura (UFMG); G. Lessa (MZUFV); J.L. Patton (MVZ); H.Q.B. Fernandes, M. Hoffmann (MBML); S. Lóss, B.M.A. Costa, J. Dalapicolla (UFES). R. Pardini, A.A. Bueno, C. Aires, G. Paise, L.P. Costa, S. Lóss, V. Fagundes, and N. Cáceres kindly allowed us to examine uncatalogued specimens under their care, and/or provided field notes and locality data. A.O. Maciel and P.L. Peloso provided suggestions in early versions. SEP and YLRL had fellowship support from Conselho Nacional de Desenvolvimento Científico e Tecnológico (CNPq).

\section{LITERATURE CITED}

Cademartori, C.V.; M.E. Fabián \& J.O. Menegheti. 2004. Variações na abundância de roedores (Rodentia, Sigmodontinae) em duas áreas de floresta ombrófila mista, Rio Grande do Sul, Brasil. Revista Brasileira de Zoociências 6: 147-167.

Carleton, M.D. 1980. Phylogenetic relationships in NeotominePermoyscine rodents (Muroidea) and a reappraisal of the dichotomy within New World Cricetinae. Miscellaneous Publications, Museum of Zoology, University of Michigan
157: $1-146$.

Carleton, M.D. \& G.G. Musser. 1989. Systematic studies of oryzomyine rodents (Muridae, Sigmodontinae): a synopsis of Microryzomys. Bulletin of the American Museum of Natural History 191: 1-83.

Cherem, J.J. 2005. Registros de mamíferos não voadores em estudos de avaliação ambiental no sul do Brasil. Biotemas 18: 169-202.

Cherem, J.J.; P.C. Simões-Lopes; S.L. Althoff \& M.E. Graipel. 2004. Lista dos mamíferos do estado de Santa Catarina, sul do Brasil. Mastozoología Neotropical 11: 151-184.

Costa, L.P.; S.E. Pavan; Y.R.L. Leite \& V. Fagundes. 2007. A new species of Juliomys (Mammalia: Rodentia: Cricetidae) from the Atlantic forest of southeastern Brazil. Zootaxa 1463: 21-37.

Dalmagro, A.D. \& E.M. Vieira. 2005. Patterns of habitat utilization of small rodents in an area of Araucaria Forest in Southern Brazil. Austral Ecology 30: 353-362.

De la Sancha, N.; G. D’Elí́a; F. Netto; P. Pérez \& J. Salazar-Bravo. 2009. Discovery of Juliomys (Rodentia, Sigmodontinae) in Paraguay, a new genus of Sigmodontinae for the country's Atlantic Forest. Mammalia 73: 162-167.

GonzÁLEZ, E.M. 2000. Un nuevo género de roedor sigmodontino de Argentina y Brasil (Mammalia: Rodentia: Sigmodontinae). Comunicaciones Zoológicas del Museo de Historia Natural de Montevideo 12: 1-12.

Lima, D.O.; B.O. Azambuja; V.L. Camilotti \& N.C. Cáceres. 2010. Small mammal community structure and microhabitat use in the austral boundary of the Atlantic Forest, Brazil. Zoologia 27: 99-105.

Melo, G.L.; J. Sponchiado; A.F. Machado \& N.C. Cáceres. 2011. Small-mammal community structure in a South American deciduous Atlantic Forest. Community Ecology 12: 58-66.

Neri-Bastos, F.A.; D.M. Barros-Battesti; P.M. Linardi; M. Amaku; A. Marcili; S.E. Favorito \& R. Pinto-da-Rocha. 2004. Ectoparasites of wild rodents from Parque Estadual da Cantareira (Pedra Grande Nuclei), São Paulo, Brazil. Revista Brasileira de Parasitologia Veterinária 13: 29-35.

Oliveira, J.A. \& C.R. Bonvicino. 2002. A new species of sigmodontine rodent from the Atlantic forest of eastern Brazil. Acta Theriologica 47: 307-322.

Oliveira, J.A.; G. Silveira; V.J. Rocha \& C.E.F. Silva. 2005. Ordem Rodentia, p. 161-191. In: N.R. Reis, A.L. Peracchi, H. FandiñoMariño \& V.J. Rocha (Eds). Mamíferos da Fazenda Monte Alegre - Paraná. Londrina, EDUEL, 224p.

Osgood, W.H. 1933. Two new rodents from Argentina. Zoological Series of the Field Museum of Natural History 20: 11-14.

Pardiñas, U.F.J \& P. Teta. 2011. On the taxonomic status of the Brazilian mouse Calomys anoblepas Winge, 1887 (Mammalia, Rodentia, Cricetidae). Zootaxa 2788: 38-44.

Pardiñas, U.F.J.; P.Teta; G. D’Elía; S. Cirignoli \& P.E. Ortiz. 2007. Resolution of some problematic type localities for 
sigmodontine Rodents (Cricetidae, Sigmodontinae), p. 391416. In: D.A. Kelt; E.P. Lessa; J. Salazar-Bravo \& J.L. Patton (Eds). The Quintessential Naturalist: Honoring the Life and Legacy of Oliver P. Pearson. Berkeley, University of California Publications in Zoology, 981p.

Pardiñas, U.F.J.; P. Teta; G. D’Elía \& C. Galliari. 2008. Rediscovery of Juliomys pictipes (Rodentia: Cricetidae) in Argentina: emended diagnosis, geographic distribution, and insights on genetic structure. Zootaxa 1758: 29-44.

PARDINI, R. \& F. UMETSU. 2006. Non-volant small mammals from the Morro Grande Forest Reserve - distribution of species and diversity in an Atlantic Forest area. Biota Neotropica 6: 1-22.

Paresque, R.; A.U. Christoff \& V. Fagundes. 2009. Karyology of the Atlantic forest rodent Juliomys (Cricetidae): A new karyotype from southern Brazil. Genetics and Molecular Biology 32: 301-305.

Tonini, J.F.R.; L.M. Carão; I.S. Pinto; J.L. Gasparini; Y.L.R. Leite \& L.P. Costa. 2010. Non-volant tetrapods from Reserva Biológica de Duas Bocas, state of Espírito Santo, southeastern Brazil. Biota Neotropica 10: 339-351.
Umetsu, F.; L. NAXARA \& R. Pardini. 2006. Evaluating the efficiency of pitfall traps for sampling small mammals in the Neotropics. Journal of Mammalogy 87: 757-765.

Vieira, E.M. \& E.L.A. MonTeiro-Filho. 2003. Vertical stratification of small mammals in the Atlantic rain forest of south-eastern Brazil. Journal of Tropical Ecology 19: 501-507.

Voss, R.V. 1993. A revision of the Brazilian muroid rodent genus Delomys with remarks on "Thomasomyine" characters. American Museum Novitates 3037: 1-44.

Wallauer, J.P.; M. Becker; L.G. Marins-SÁ; L.M. Liermann; S.H. Perretto \&V. Schermack. 2000. Levantamento dos mamíferos da Floresta Nacional de Três Barras - Santa Catarina. Biotemas 13: 103-127.

Submitted: 09.XII.2010; Accepted: 04.VII.2011. Editorial responsibility: Ana Lúcia da C. Prudente

Appendix I. Gazetteer of collecting localities and specimens examined. All localities included are based on voucher specimens analyzed by us (voucher numbers are underlined) or reported in the literature (Cherem et al. 2004, Cherem 2005, Oliveira et al. 2005, Pardiñas et al. 2008, Paresque et al. 2009, De La Sancha et al. 2009, Lima et al. 2010, Melo et al. 2011). Specimens identified only as Juliomys sp. in the original references (Cherem et al. 2004, Cherem 2005, Paresque et al. 2009) are listed here as such. Numbers in bold correspond to numbered localities on the map (Fig. 13). All localities are numbered from north to south. Countries are listed in small caps, followed by larger administrative units in italics, smaller administrative units, specific localities, latitude and longitude (south and west, respectively, in negative decimal degrees), and elevation in meters.

Juliomys ossitenuis: Brazıl: Espírito Santo: Castelo: 6. Parque Estadual do Forno Grande, -20.52 -41.00, 1200-2039 m (MBML 2607); Dores do Rio Preto: 4. Casa Queimada, Parque Nacional do Caparaó, -20.46 -41.81, 2079 m (MBML 2784); 5. Macieira, Parque Nacional do Caparaó, -20.48 -41.83, 1788 m (MBML 2783). Minas Gerais: Fervedouro: 7. Fazenda Neblina, Parque Estadual da Serra do Brigadeiro, 20 km W Fervedouro, -20.72 -42.48, 1300 m (type locality, MN 69752-53, UFMG 3174, MZUFV 608, 627, 679, 683); Passa Quatro: 10. Fazenda do Itaguaré, 16 km SW Passa Quatro, -22.47 -45.08, 1500 m (UFMG 3173). São Paulo: Bananal: 11. Estação Ecológica do Bananal, -22.80 -44.37, 1119-1164 m (MZUSP uncatalogued EEB 536-37, 542, 549, 596, 602); Cotia: 17. Sítio Até Que Enfim, Caucaia do Alto, ca. -23.68 -47.03, 900 m (MZUSP 33170-71); 18. Quilombo, Reserva Florestal do Morro Grande, Caucaia do Alto, -23.76 -47.00, 800-1000 m (MZUSP 32648); 19. Grilos, Reserva Florestal do Morro Grande, Caucaia do Alto, 23.78 -47.01, 800-1000 m (MZUSP 32650); Piedade: 23. Cristo, -23.85 -47.47, 800-1000 m (MZUSP uncatalogued AB 473); 24. Fragmento Eme, -23.88 -47.48, 800-1000 m (MZUSP uncatalogued AB 258); Tapiraí: 25. Fragmento Antenor, -23.92 -47.45, 8001000 m (MZUSP uncatalogued $A B$ 196); 26. Janzinho, -23.97 -47.51, 800-1000 m (MZUSP uncatalogued AB 469); Ribeirão Grande: 35. Mulheres, -24.05 -48.37, 800-1000 m (MZUSP uncatalogued AB 350, 357); 36. Museros -24.22 -48.40, 800-1000 m (MZUSP uncatalogued AB 395); 33. Mina Limeira, -24.17 -48.33, 800-1000 m (MZUSP 32276).

Juliomys pictipes: BrazlL: Espírito Santo: Cariacica: 3. Reserva Biológica Duas Bocas, Alto Alegre, -20.28 -40.51, 550 m (UFES 556-557). Minas Gerais: Santa Bárbara: 1. Estação de Pesquisa e Desenvolvimento Ambiental de Peti, -19.9 -43.37, 630-806 m (UFMG 316164); 2. Reserva Particular do Patrimônio Natural do Caraça, 25 km SW Santa Bárbara, -20.08 -43.5, 1300 m (MN 69764, UFMG 3159-60). Rio de Janeiro: Teresópolis: 9. Fazenda Boa Fé, -22.43 -42.98, 902 m (MN 62182); Angra dos Reis: 12. Mata do Mamede, ca. -23 -44.32 (MN 69765). São Paulo: São Luís do Paraitinga: 13. Fragmento G4, -23.22 -45.31, 900 m (ZUEC-MAM 2399); Sorocaba: 14. Floresta Nacional de Ipanema, 20 km NW Sorocaba, -23.44 -47.63, 701 m (MVZ 197563-65, UFMG 3165-72); Mogi da Cruzes: 15. Parque Natural Municipal da Serra do Itapety, -23.47 -46.15, 807-1141 m (MN uncatalogued 61); Cotia: 16. Reserva Florestal do Morro Grande, Caucaia do Alto -23.68 -46.96, 800-1000 m (MZUSP 32263-66, 32649); Piedade: 20. No specific locality provided, ca. -23.72 -47.41, 800-1000 m (MZUSP 31113); São Bernardo do Campo: 21. Riacho Grande, ca. -23.80 -46.58, 777 m 
(MZUSP 30710, 30724, 30747, 30779); Buri: 22. No specific locality provided, ca. -23.81 -48.70, $666 \mathrm{~m}$ (MZUSP 31025); Ribeirão Grande: 35. Mulheres, -24.05 -48.37, 800-1000 m (MZUSP uncatalogued AB 348, 388, 410); 36. Museros, -24.22 -48.40, 800$1000 \mathrm{~m}$ (MZUSP uncatalogued $A B$ 402, 562); 27. Fragmento Citadini, -24.06 -48.39, 800-1000 m (MZUSP uncatalogued $A B$ 78); 28. Fragmento Divisa, -24.06 -48.37, 800-1000 m (MZUSP uncatalogued AB 75); 29. Três Quedas, -24.22 -48.37, 800-1000 m (MZUSP uncatalogued $A B$ 571); 30. Moacir, -24.22 -48.37, 800-1000 m (MZUSP uncatalogued $A B$ 378); 31. Paraguai, -24.23 48.39, 800-1000 m (MZUSP uncatalogued AB 559, 591); 32. Cogumelo -24.23 -48.38, 800-1000 m (MZUSP uncatalogued $\underline{A B}$ 557); Capão Bonito: 37. Fazenda Sakamoto, Campinho, -24.18 -48.24, 800-1000 m (MZUSP uncatalogued AB 110, 113, 115, 141, 143, 145); 38. Fazenda Sakamoto, Portão, -24.18 -48.24, 800-1000 m (MZUSP uncatalogued AB 124); 39. Fazenda Intervales, -

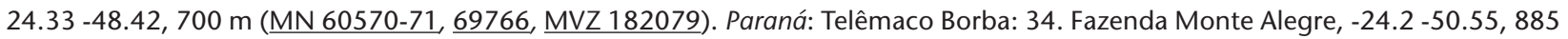
m (MN 68336, MN 68347). Santa Catarina: Santo Amaro da Imperatriz: 48. No specific locality provided, $-27.68-48.78$, no elevation provided (UFSC 652, UFSC 670, UFSC 862-864. Rio Grande Do Sul: Derrubadas: 47. Parque Estadual do Turvo, -27.13 -53.8, 100-400 m (no voucher number provided). ArGentina: Misiones: Cainguas: 46. Reserva Privada de Usos Múltiples de la Universidad Nacional de La Plata "Valle del Arroyo Cuña Pirú", -27.08 -54.95, ca. 200 m (MLP 1.I.03.24); Iguazú: 41. Parque Nacional Iguazú, Sendero Macuco, -25.68 -54.43, ca. 200 m (CIES-M 23); Montecarlo: 45 Puerto Caraguatay -26.62 -54.76, 192 m (type locality, FMNH 26814); 44. Parque Provincial "Ernesto Che Guevara" Arroyo de Salamanca -26.61 -54.78, 147 m (CNP 895). Paracuar: Alto Paraná: Hernandarias: 40. Refugio Biológico Limoy, North of Rio Limoy, -24.80 -54.45, ca. 270 m (CZ 014).

Juliomys rimofrons: Brazıl: Minas Gerais: Itamonte: 8. Brejo da Lapa, -22.35 -44.73, 2000 m (type locality, MN 46703, 61646-47).

Juliomys sp.: Brazıl: Santa Catarina: Florianópolis: 49. Ilha de Santa Catarina, Parque Municipal da Lagoa do Peri, -27.72 -48.53, 5-60 m, (UFSC 905); Itapoá: 43. No specific locality provided, -26.12 -48.62, no elevation provided (UFSC 2960-66); Siderópolis: 50. Barragem do Rio São Bento, -28.60 -49.55, ca.190 m (UFSC 3404); Três Barras: 42. Floresta Nacional de Três Barras, -26.11 -50.32, 700-800 m (UFSC 950). Rio Grande Do Sul: São Francisco de Paula: 51. Aparados da Serra National Park, -29.19 -50.09, 800 m (MNCU 464, MNCU 868-869); Santa Maria: 52. Morro do Elefante, -29.67 -53.72, 260-460 m (UFSM 446).

Oligoryzomys flavescens: Brazil: Espírito Santo: Dores do Rio Preto: Casa Queimada, Parque Nacional do Caparaó, -20.46 -41.81, 2079 m (UFES $1176, \underline{1033}, \underline{1255}$, uncatalogued CP 381); Macieira, Parque Nacional do Caparaó, -20.48 -41.83, $1788 \mathrm{~m}$ (UFES $\underline{1177}, \underline{1178}$, 1179).

Rhagomys rufescens: Brazil: Espírito Santo: Santa Teresa: Valsugana Velha, -19.97 -40.53, ca. 550-700 m (MBML 2327); São Paulo: Ribeirão Grande: Mulheres, -24.05 -48.37, 800-1000 m (MZUSP uncatalogued AB 356); Paraguai, -24.23 -48.39, 800-1000 m (MZUSP uncatalogued $A B$ 401). 